\title{
Boosting Achene Yield and Yield Related Traits of Sunflower Hybrids through Boron Application Strategies
}

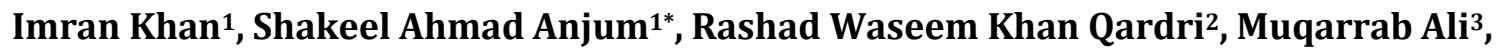 \\ Muhammad Umer Chattha', Muhammad Asif ${ }^{1}$ \\ ${ }^{1}$ Department of Agronomy, University of Agriculture, Faisalabad, Pakistan \\ ${ }^{2}$ Institute of Horticultural Sciences, University of Agriculture, Faisalabad, Pakistan \\ ${ }^{3}$ Department of Agronomy, Muhammad Nawaz Shareef University of Agriculture, Multan, Pakistan \\ Email: ${ }^{*}$ drimran@uaf.edu.pk
}

Received 20 May 2015; accepted 20 July 2015; published 23 July 2015

Copyright (C) 2015 by authors and Scientific Research Publishing Inc.

This work is licensed under the Creative Commons Attribution International License (CC BY).

http://creativecommons.org/licenses/by/4.0/

(c) (i) Open Access

\section{Abstract}

Effects of different boron (B) application methods on growth and yield of sunflower hybrids were checked out at Agronomic Research Farm, University of Agriculture, Faisalabad, Pakistan during spring, 2013. Field experiment was conducted by considering three sunflower hybrids viz., Patron 551, Patron 851 and S-278 along with different methods of $B$ application i.e. no B application, seed

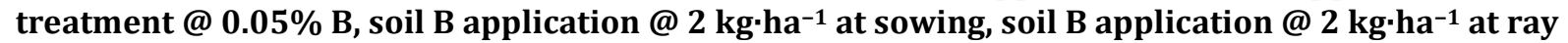
floret stage and foliar application of B @ $200 \mathrm{mg} \cdot \mathrm{L}^{-1}$ at ray floret stage. Uttermost plant height $(150.78 \mathrm{~cm})$, the number of leaves per plant $(22.67)$ and stem diameter $(1.62 \mathrm{~cm})$ were accomplished when boron was soil applied @ $2 \mathrm{~kg}^{-h^{-1}}$ at sowing. Significantly higher head diameter $(18.30 \mathrm{~cm})$, number of achene per head $(1266.44), 1000$-achene weight $(43.17 \mathrm{~g})$ achene yield $\left(2039.33 \mathrm{~kg} \cdot \mathrm{ha}^{-1}\right)$, biological yield $\left(9223.11 \mathrm{~kg} \cdot \mathrm{ha}^{-1}\right)$ and harvest index $(22.10 \%)$ were registered when boron was foliar applied @ $200 \mathrm{mg} \cdot \mathrm{L}^{-1}$ at ray floret stage. Among sunflower hybrids, Patron 551 produced significantly higher growth and yield attributes as compared with Patron 851 and S-278 hybrids. This study suggested that the selection of Patron 551 hybrid with practicing boron foliar application @ $200 \mathrm{mg} \cdot \mathrm{L}^{-1}$ at ray floret stage could be helpful in achieving the sunflower crop genetic potential.

\section{Keywords}

Boron Application Methods, Sunflower Hybrids, Biological Yield, Achene Yield Growth and Yield Attributes

\footnotetext{
${ }^{*}$ Corresponding author.
}

How to cite this paper: Khan, I., Anjum, S.A., Qardri, R.W.K., Ali, M., Chattha, M.U. and Asif, M. (2015) Boosting Achene Yield and Yield Related Traits of Sunflower Hybrids through Boron Application Strategies. American Journal of Plant Sciences, 6, 1752-1759. http://dx.doi.org/10.4236/ajps.2015.611175 


\section{Introduction}

Throughout the world, sunflower is one of the most authoritative sources of vegetable oil. Sunflower ranks third in the world for total production of oilseeds [1]. It is an important oil seed crop having $20 \%-27 \%$ protein and $40 \%-47 \%$ oil content [2] and a prolific source of vitamins A and D. Its oil is called premium oil due to presence of oleic acid (16.2\%) and linolenic acid (72.5\%) with high \% age (60\%) of poly unsaturated fatty acids [3]. The oil is used for cooking purposes and preparation of margarine. In Pakistan, sunflower yield is far abject than the genetic potential of the crop. The introduction of high yielding hybrids has increased the yield but still there is a wider gap between potential and farmer field yield. There are several reasons which can be conceived responsible for low productivity. But deficiency of micronutrients and poor performance of selected hybrids are two of the major drives of miserable yield of sunflower in Pakistan.

Selection of appropriate hybrids is the key factor to get maximal yield. Adoption of good cultivars improves not only yield but also its quality [4]. Iqbal et al. (2011) [5] discovered that sunflower hybrid S-278 produced significantly taller plants, heavier 1000-achene weight, more achene and stalk yield as compared with hybrid Hyssun-33. Micronutrient deficiencies not only are impeding crop productivity but also are devolving produce quality. Application of micronutrients also helps in improving the availability of micronutrients (Johnson et al., 2005) [6]. Among the micronutrients Boron is very important in controlling many physiological and biochemical activities in plants. In Pakistan Boron deficiency is generally observed in cotton growing areas (Abid et al., 2002) [7]. Calcareous soils of wheat and rice growing areas are also deficient in available B; yield of these crops can be increased by application of balanced fertilizers including Boron (Rashid and Ryan, 2004) [8].

Boron is important in cell walls; both B deficiency and toxicity stimulate lower chlorophyll levels and the rate of photosynthesis, and can disturb the maintenance of meristems in plants (Bolanos et al., 2004) [9]. Boron deficiency can cause drop in root elongation and mostly leaf nitrate contents without disturbing nitrate reduce activity or the concentrations of other micronutrients such as magnesium, calcium, phosphate or potassium (Camacho-Cristobal et al., 2005) [10]. Boron deficiency can be subdued by different agronomic techniques, for example it can be overcome by supplying it through seed priming, soil application, and foliar application at different growth stages of the crop.

The present study was, therefore, conducted to evaluate the performance of three sunflower hybrids upon different methods of boron application.

\section{Materials and Methods}

The study was conducted at Agronomic Research Farm, University of Agriculture, Faisalabad, Pakistan $\left(31^{\circ} 25^{\prime} \mathrm{N}, 73^{\circ} 04^{\prime} \mathrm{E}\right)$ during spring, 2013 under the semi-arid and subtropical climatic conditions. Monthly trends of temperature, rainfalls, relative humidity (R.H.) and sun shine hours, averaged over the crop growing period are given in Figure 1. Soil analysis (Table 1) depicted that study area soil was sandy clay loam and organic matter, nitrogen, phosphorus, potassium and boron soil contents were less than plant optimal range. The experiment was laid out in RCBD with factorial arrangement and each treatment was replicated thrice. Experiment was comprised of sunflower hybrids Patron 551, Patron 851 and S-278 as well as different boron application methods $\mathrm{B}_{0}=$ No B application, $\mathrm{B}_{1}=$ Seed priming with $\mathrm{B}(0.05 \%), \mathrm{B}_{2}=$ Soil B application $\left(2 \mathrm{~kg} \cdot \mathrm{ha}^{-1}\right)$ at sowing, $B_{3}=$ Soil B application $\left(2 \mathrm{~kg} \cdot \mathrm{ha}^{-1}\right)$ at ray floret stage, $\mathrm{B}_{4}=$ Foliar application of $\mathrm{B}\left(200 \mathrm{mg} \cdot \mathrm{L}^{-1}\right)$ at ray floret stage. Boric acid was used as a source of boron for different treatments. Seed of sunflower hybrids were collected from Pioneer seed and Syngenta seed companies. For priming, seeds were soaked in aerated boric acid solution (as per treatment) keeping seed to solution ratio of 1:10 (w/v) for $12 \mathrm{~h}$. Primed seeds were given three surface washings with distilled water and were dried to the original moisture level, after which they were sealed in polythene bags. The net plot size of each plot was $4.0 \mathrm{~m} \times 2.4 \mathrm{~m}$ and each plot had 4 rows. Sunflower hybrids were sown in $60 \mathrm{~cm}$ apart rows having a plant to plant distance of $25 \mathrm{~cm}$, using dibbler by dropping 2 seeds per hill and then after germination one plant per hill was maintained by thinning. Seed rate of $6.25 \mathrm{~kg} \cdot \mathrm{ha}^{-1}$ was used for crop sown. The fertilizer NPK was applied @ 150, 100, $62 \mathrm{~kg} \cdot \mathrm{ha}^{-1}$ respectively. The complete dose of phosphorus and potassium and 1/3 of nitrogen was applied at the time of sowing. Remaining nitrogen was applied in 3 splits with first, second and third irrigation. Boron was applied as per treatment. Plant protection measures were adopted to keep crop free from weeds, insect pests and diseases. The crop was harvested on July 8, 2013. Parameters concerning with yield such as number of leaves per plant, plant height, stem diameter, head diameter, 1000-achene weight, achene yield and biological yield were recorded during the crop period. All the 


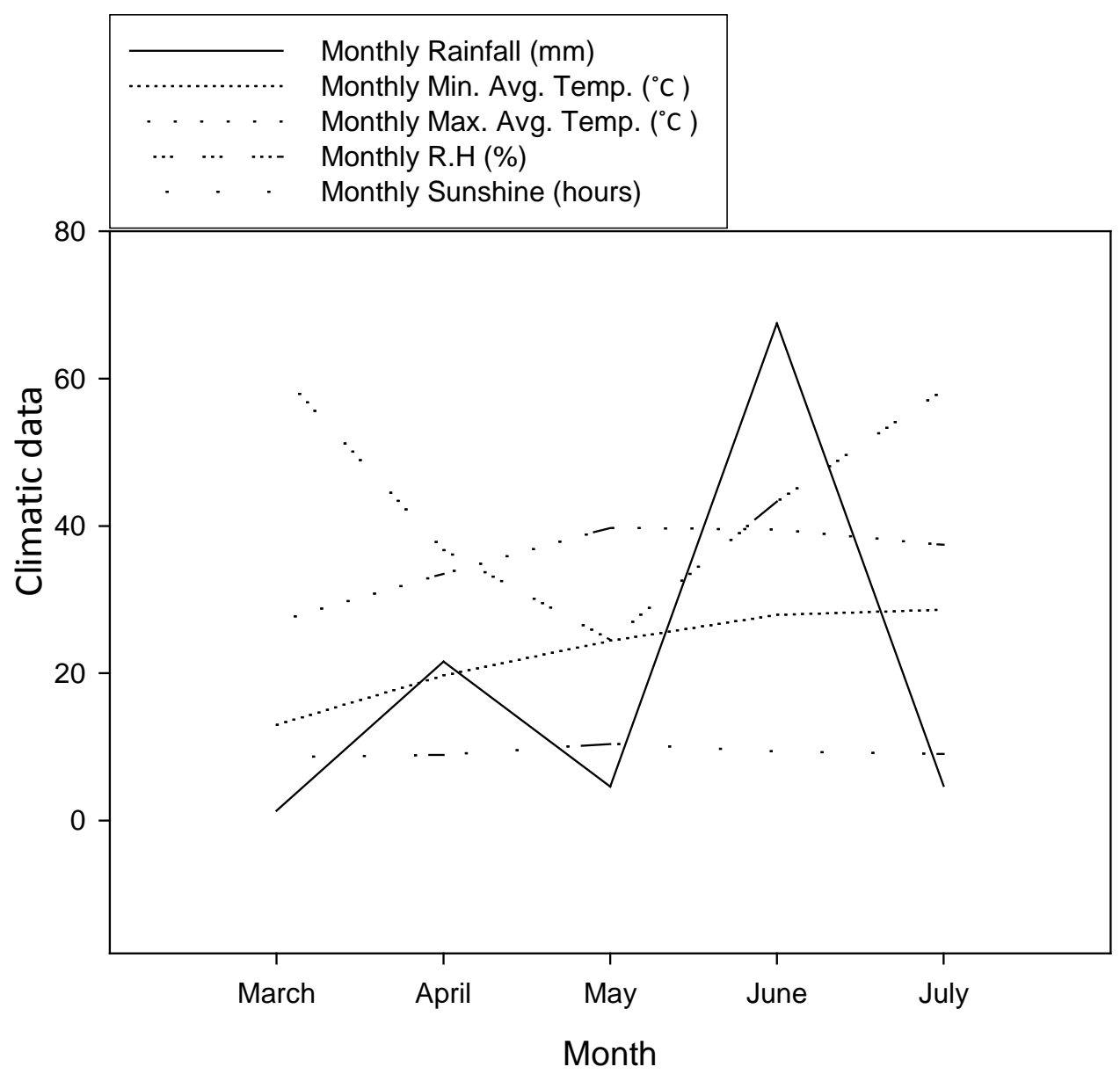

Figure 1. Mean climatic data during crop growing season at experimental site.

Table 1. Physico-chemical analysis of soil.

\begin{tabular}{ccc}
\hline Chemical analysis & Experimental site value & Status \\
\hline $\mathrm{pH}$ & 7.6 & Alkaline \\
EC $\left(\mathrm{dS} \cdot \mathrm{m}^{-1}\right)$ & 1.2 & Normal \\
Organic matter (\%) & 0.79 & Low \\
$\mathrm{N}(\%)$ & 0.047 & Low \\
$\mathrm{P}(\mathrm{ppm})$ & 8.75 & Low \\
K (ppm) & 165 & Sufficient \\
Boron (B) (ppm) & 0.41 & Deficient \\
Physical analysis & & \\
Sand (\%) & 65 & Sandy clay loam soil \\
Silt (\%) & 16 & \\
Clay (\%) & 19 & \\
\hline
\end{tabular}

parameters were appraised according to standard methodology and the data taken was analyzed employing Statistic 8.1. Least significance difference (LSD) test was used to compare the different treatment means at 5\% 
probability (Steel et al., 1997) [11].

\section{Results and Discussion}

\subsection{Number of Leaves per Plant at Flowering}

Sunflower hybrids differ significantly in terms of number of leaves per plant at flowering stage. Topmost number of leaves (26.13) per plant was recorded for Patron-551 while the low most (20.80) were recorded in Patron 851 that was also at par with S-278 (20.93). Number of leaves per plant was substantially affected by different boron application methods. Maximal number of leaves (23.33) was obtained where B was applied as soil applied @ $2 \mathrm{~kg} \cdot \mathrm{ha}^{-1}$ at sowing that was at par with all other B application treatments. The minimal numbers of leaves (21.89) were produced in control. The interaction between sunflower hybrids and boron application methods was non-significant (Table 2). These results are in line with the findings of El-Shintinway, (1999) [12] who also had provided the evidence regarding the positive effects of B on number of leaves of sunflower plant.

\subsection{Plant Height at Maturity (cm)}

Table 1 revealed the differences in plant height according to different treatments. The hybrids differ substantially in plant height. The sunflower hybrid Patron 551 gave the greatest plant height $(175.67 \mathrm{~cm})$. The effect of different methods of boron application at various stages of sunflower was also highly significant on plant height. Greatest plant height $(156.78 \mathrm{~cm})$ was obtained from soil B application @ $2 \mathrm{~kg} \cdot \mathrm{ha}^{-1}$ at sowing that was also at par with foliar application of B $200 \mathrm{mg} \cdot \mathrm{L}^{-1}$ at ray floret stage and soil B application @ $2 \mathrm{~kg} \cdot \mathrm{ha}^{-1}$ at ray floret stage. Least plant height $(141 \mathrm{~cm})$ was discovered in control treatment. Enhancement in plant height might be due to appropriate dose of boron. These results are in accordance with (Gitte et al., 2005 and Kolesnikov et al., 2008) [13] [14]. Oyinlola (2007) [15] also explained that sunflower plant height show positive response to applied boron.

\subsection{Stem Diameter (cm)}

Considerable differences in stem diameter of sunflower hybrids were observed during the study. Maximal stem diameter $(1.81 \mathrm{~cm})$ was achieved in Patron 551 that was followed by Patron $851(1.58 \mathrm{~cm})$. Slightest stem diameter $(1.50 \mathrm{~cm})$ was achieved in S-278 sunflower hybrid. Influence of boron application methods was highly significant on stem diameter of sunflower hybrids. The maximal stem diameter $(1.70 \mathrm{~cm})$ was obtained from plots where boron was applied as soil application @ $2 \mathrm{~kg} \cdot \mathrm{ha}^{-1}$ at sowing while all the other boron application methods show statistically similar stem diameter (Table 2). These results coincide with the finding of O'Neil et al. (2004) [16]. These scientists evaluated that boron deficiency affects the cell enlargement in growing tissues as it is involved in cell structure hence reduce stem diameter. These results are in confirmation with the discovery of Silva et al. (2011) [17] they reported that in sunflower there was increase in stem diameter when boron was applied at sowing time.

\subsection{Head Diameter (cm)}

Data exhibited in Figure 2 that the head diameter was highest $(18.88 \mathrm{~cm})$ in Patron 551 that was followed by S-278 $(17.14 \mathrm{~cm})$ and it was lowest $(16.37 \mathrm{~cm})$ in Patron 851 . Head diameter is also highly significantly affected by the different boron application methods. The foliar application of B @ $200 \mathrm{mg} \cdot \mathrm{L}^{-1}$ at ray floret stage gave the uttermost head diameter $(18.30 \mathrm{~cm})$ that was followed by soil B application @ 2 kg·ha ${ }^{-1}(17.67 \mathrm{~cm})$. Least head diameter was recorded for control treatment. These results are in line with Zahoor et al. (2011) [18] who discovered that maximum head diameter $(21.2 \mathrm{~cm})$ was recorded in plants applied with $2 \mathrm{~kg}$ boron per hectare. The interactive effect of sunflower hybrids and boron application methods was also found significant for head diameter (Figure 2). Maximum head diameter $(19.89 \mathrm{~cm})$ was recorded where boron was applied as foliar @ 200 $\mathrm{mg} \cdot \mathrm{L}^{-1}$ at ray floret stage to hybrid Patron 551. However, minimal head diameter $(14.07 \mathrm{~cm})$ was observed in the plots where Patron 551 was sown after priming with $0.05 \%$ boron solution. The stimulatory effect of boron on sunflower plant may be due to its role in enhancing metabolic process and improving development of pollen tube. These results also coincide with scientists Renukadevi and Savithr (2003) [19] and similar with Shekhawat and Shivay (2008) [20]. They reported that head diameter was increased with boron application because of augmentation in pollen-production capacity of anthesis and pollen grain viability. 


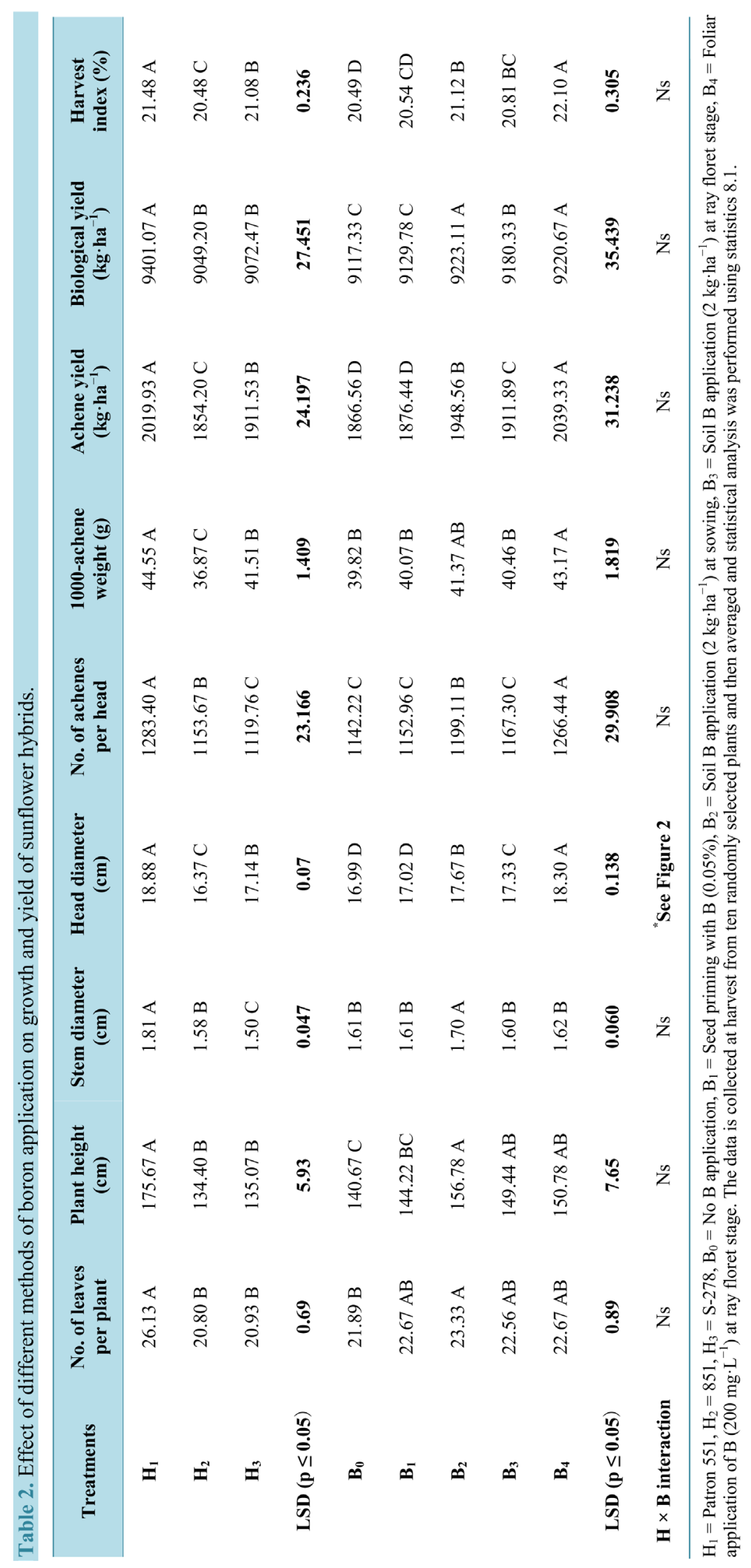




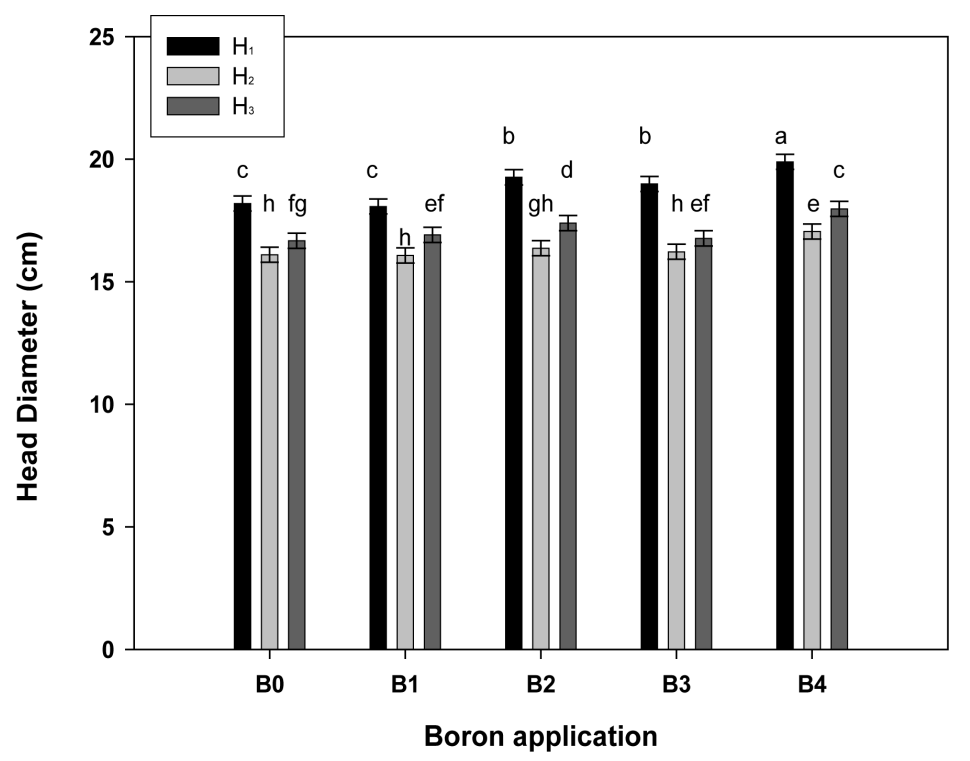

Figure 2. Effect of different methods of boron application on Head diameter (cm) of sunflower hybrids. $\mathrm{H}_{1}=\mathrm{Patron}^{551, \mathrm{H}_{2}}$ $=851, \mathrm{H}_{3}=\mathrm{S}-278, \mathrm{~B}_{0}=$ No B application, $\mathrm{B}_{1}=$ Seed priming with $\mathrm{B}(0.05 \%), \mathrm{B}_{2}=$ Soil B application $\left(2 \mathrm{~kg} \cdot \mathrm{ha}^{-1}\right)$ at sowing, $\mathrm{B}_{3}=$ Soil B application $\left(2 \mathrm{~kg} \cdot \mathrm{ha}^{-1}\right)$ at ray floret stage, $\mathrm{B}_{4}=$ Foliar application of $\mathrm{B}\left(200 \mathrm{mg} \cdot \mathrm{L}^{-1}\right)$ at ray floret stage. The head diameter of ten plants for all the treatments was measured with the help of measuring tape at crop maturity stage and then statistically analyzed. The bars indicate the interaction between sunflower hybrids and boron application methods.

\subsection{Number of Achenes per Head}

Most number of achene (1283) per head were discovered in hybrid Patron 551. Among different boron application methods, foliar application of B @ $200 \mathrm{mg} \cdot \mathrm{L}^{-1}$ at ray floret stage gave the best results of achenes (1266) per head. The interaction was non-significant between hybrids of sunflower and boron application methods (Table 2). The increase in number of achene per head might be due to the role of boron in pollen tube germination. These results coincided with the findings of Ghani et al. (2000); Khan et al. (2000) [21] [22] they gave the evidence of positive effects of B application on number of achene in sunflower crop. Parkash and Mehra (2006) [23] also found that boron application significantly enhanced the number of achenes per head.

\subsection{0-Achene Weight (g)}

The data encompassing 1000-achene weights (Table 2) exhibited that uppermost 1000-achene weight (44.55 g) was accomplished from Patron 551. Different boron application methods also showed significant results. Highest 1000-achene weight (43.17 g) was obtained from foliar application of B @ $200 \mathrm{mg} \cdot \mathrm{L}^{-1}$ at ray floret stage that was also at par with soil applied boron @ $2 \mathrm{~kg} \cdot \mathrm{ha}^{-1}$ at sowing. Low most 1000-achene weight (39.82 g) was obtained where no B was applied. The interaction between hybrids and boron application methods showed nonsignificant results. The increase in 1000-achene weight might be due to the role of boron in pollination and achene filling. These results substantiate the finding of Oyinlola (2007) [15] and Bilen et al. (2011) [24] they reported that application of boron increases 1000-achene weight as application of boron helped in enhancing the dehydrogenase and phosphatase enzymes activity. The same results were discovered by Reddy et al. (2003) [25] who commented that increased 1000 -achene weight of sunflower by the application of boron might be due to increased translocation of photosynthates from vegetative sources towards the reproductive organs.

\subsection{Achene Yield $\left(\mathrm{kg} \cdot \mathrm{ha}^{-1}\right)$}

The highest achene yield (2020 kg·ha ${ }^{-1}$ ) was accomplished by hybrid Patron 551 followed by S-278 (1911 $\mathrm{kg} \cdot \mathrm{ha}^{-1}$ ). The foliar application of boron @ $200 \mathrm{mg} \cdot \mathrm{L}^{-1}$ at ray floret stage produced highest achene yield (2039 $\left.\mathrm{kg} \cdot \mathrm{ha}^{-1}\right)$ and low most achene yield (1866 kg $\mathrm{ha}^{-1}$ ) was produced in case of treatment of no boron application. The interactive effect of both hybrids and boron application methods was found non-significant (Table 2). Reddy et al. (2003) [25] explained that increased achene yield of sunflower due to active role of boron in transloca- 
tion of photosynthates especially when applied at ray floret stage. Similar results were discovered by Castro et al. (2006) [26] who found an increased achene yield of sunflower by the application of boron.

\subsection{Biological Yield (kg:ha-1)}

Highly significant differences in biological yield were observed in three sunflower hybrids as heaviest biological yield (9401 kg· ha ${ }^{-1}$ ) was accomplished by hybrid Patron 551. The effect of B application methods on biological yield was also highly significant. Maximal biological yield $\left(9223 \mathrm{~kg} \cdot \mathrm{ha}^{-1}\right.$ ) was obtained with soil B application @ $2 \mathrm{~kg} \cdot \mathrm{ha}^{-1}$ at sowing which was statistically at par with foliar application of boron @ $200 \mathrm{mg} \cdot \mathrm{L}^{-1}$ at ray floret stage. The control treatment produced lowest $\left(9117 \mathrm{~kg} \cdot \mathrm{ha}^{-1}\right.$ ) biological yield (Table 2). These results are in line with the findings of Gitte et al. (2005) [13] they reported that increase in biological yield might be due to role of boron in cell elongation, cell division and biomass accumulation. Increase in biological yield may be due to active role of boron in cell elongation, cell division and biomass accumulation.

\subsection{Harvest Index (\%)}

All sunflower hybrids differ substantially in their harvest index. Most eminent harvest index (21.48\%) was reached in case of hybrid patron 551 and most down harvest index (20.48\%) was observed in hybrid Patron 851. Maximal harvest index (22.10\%) was attained with foliar application of B @ $200 \mathrm{mg} \cdot \mathrm{L}^{-1}$ at ray floret stage and minimal (20.49\%) was observed in control treatment (Table 2). These results are in line with those of Silva et al. (2011). Increased value of harvest index by the application of boron has also been described by Reddy et al. (2003) [25]. The interaction between hybrids and boron application was non-significant (Table 2).

\section{Conclusion}

It was obvious from the results that sunflower hybrid Patron 551 and foliar application of B $\left(200 \mathrm{mg} \cdot \mathrm{L}^{-1}\right)$ at ray floret stage brought maximal results. So farming community should prefer sunflower hybrid Patron 551 over other Patron 851 and S-278 hybrids and foliar application of B (200 mg. $\left.\mathrm{L}^{-1}\right)$ at ray floret stage should be practiced under semi-arid conditions of Faisalabad for robust and healthy crop.

\section{References}

[1] Ramulu, N., Jayadeva, H.M., Venkatesha, M.M. and Kumar, H.R. (2011) Seed Yield and Nutrient Uptake of Sunflower (Helianthus annuus L.) as Influenced by Different Levels of Nutrients under Irrigated Condition of Eastern Dry Zone of Karnataka, India. Plant Archives, 11, 1061-1066.

[2] Saleem, R., Farooq, M.U. and Ahmed, R. (2003) Bio-Economic Assessment of Different Sunflower Based Intercropping Systems at Different Geometric Configurations. Journal of Biological Sciences, 6, 1187-1190.

[3] Rathore, P.S. (2001) Technique and Management of Field Crop Production. Agro Bios, India, 215-220.

[4] Awasthi, C.P., Abidi, A.B. and Choudhry, A.R. (1991) Studies on the Nutritional Quality of Different Varieties of Chickpea. Indian Journal of Agricultural Research, 25, 21-26.

[5] Iqbal, J., Randhawa, M.A., Rasheed, M. and Khan, H.A. (2011) Morphological Features in Sunflower as Influenced by Varying Nutritional Area. Pakistan Journal of Nutrition, 10, 470-474. http://dx.doi.org/10.3923/pjn.2011.470.474

[6] Johnson, S.E., Lauren, J.G., Welch, R.M. and Duxbury, J.M. (2005) A Comparison of the Effects of Micronutrient Seed Priming and Soil Fertilization on the Mineral Nutrition of Chickpea (Cicer arietinum), Lentil (Lens culinaris), Rice (Oryza sativa) and Wheat (Triticum aestivum) in Nepal. Experiment Agriculture, 41, 427-448. http://dx.doi.org/10.1017/S0014479705002851

[7] Niaz, A., Ibrahim, M., Ahmad, N. and Anwar, S.A. (2002) Boron Contents of Light and Medium Textured Soils and Cotton Plants. International Journal of Agriculture and Biology, 4, 534-536.

[8] Rashid, A. and Ryan, J. (2004) Micronutrient Constraints to Crop Production in Soils with Mediterranean-Type Characteristics: A Review. Journal of Plant Nutrition, 27, 959-975. http://dx.doi.org/10.1081/PLN-120037530

[9] Bolanos, L., Lukaszewski, K., Bonilla, I. and Blevins, D. (2004) Why Boron? Plant Physiology and Biochemistry, 42, 907-912. http://dx.doi.org/10.1016/j.plaphy.2004.11.002

[10] Camacho-Cristobal, J.J., Maldonado, J.M. and Gonzalez-Fontes, A. (2005) Boron Deficiency Increases Putrescine Levels in Tobacco Plants. Journal of Plant Physiology, 162, 921-928. http://dx.doi.org/10.1016/j.jplph.2004.09.016

[11] Steel, R., Torrie, J. and Dickey, D. (1997) Principals and Production of Statistics. A Biometrical Approach. 3rd Edition, 
McGraw-Hill Book Co., New York.

[12] El-Shintinawy, F. (2000) Structural and Functional Damage Caused by Boron Deficiency in Sunflower Leaves. Photosynthetica, 36, 565-573. http://dx.doi.org/10.1023/A:1007096105491

[13] Gitte, A.N., Patil, S.R. and Tike, M.A. (2005) Influence of Zinc and Boron on Biochemical and Yield Characteristics of Sunflower. Indian Journal of Plant Physiology, 10, 400-403.

[14] Kolesnikov, S.I., Popovich, A.A., Kazeev, K.S. and Val’kov, V.F. (2008) The Influence of Fluorine, Boron, Selenium, and Arsenic Pollution on the Biological Properties of Ordinary Chernozems. Eurasian Soil Science, 41, 400-404. http://dx.doi.org/10.1134/S1064229308040066

[15] Oyinlola, E.Y. (2007) Effect of Boron Fertilizer on Yield and Oil Content of Three Sunflower Cultivars in the Nigerian Savanna. Journal of Agronomy, 6, 421-426. http://dx.doi.org/10.3923/ja.2007.421.426

[16] O’Neill, M.A., Ishii, T., Albersheim, P. and Darvill, A.G. (2004) Rhamnogalacturonan II: Structure and Function of a Borate Cross-Linked Cell Wall Pectic Polysaccharide. Annual Review of Plant Biology, 55, 109-139. http://dx.doi.org/10.1146/annurev.arplant.55.031903.141750

[17] da Silva, C.A.T., Cagol, A., da Silva, T.R.B. and Nobrega, L.H.P. (2011) Boron Application before Sowing of Sunflower Hybrids. Journal of Food, Agriculture and Environment, 9, 580-583.

[18] Zahoor, R., Basra, S.M.A. Munir, H., Nadeem, M.A. and Yousaf, S. (2011) Role of Boron in Improving Assimilate Partitioning and Achene Yield in Sunflower. Journal of Agriculture and Social Sciences, 7, 49-55.

[19] Renukadevi, A. and Savithri, P. (2003) Sunflower (Helianthus annuus L.) Oil Yield and Quality as Influenced by Boron Application. Madras Agriculture Journal, 91, 74-76.

[20] Shekhawat, K. and Shivay, Y.S. (2008) Effect of Nitrogen Source, Sulphur and Boron Levels on Productivity, Nutrient Uptake and Quality of Sunflower (Helianthus annuus L.). Indian Journal of Agronomy, 53, 129-134.

[21] Ghani, A., Hussain, M. and Qureshi, M.S. (2000) Effect of Different Irrigation Regimens on the Growth and Yield of Sunflower. International Journal of Agriculture and Biology, 2, 334-335.

[22] Khan, A., Iqbal, M., Ahmad, I., Iqbal, N. and Hussain, M. (2000) Effect of Different Water Stress Levels on Yield and Oil Content of Sunflower (Helianthus annuus L.) Cultivators. Pakistan Journal of Biological Sciences, 3, 1632-1633. http://dx.doi.org/10.3923/pjbs.2000.1632.1633

[23] Parkash, Y.R. and Mehra, P.M. (2006) Growth and Yield of Sunflower as Influenced by Nitrogen and Boron Nutrition. (CAB ABSTRACT).

[24] Bilen, S., Bilen, M. and Bardhan, S. (2011) The Effect of Boron Management on Soil Microbial Population and Enzyme Activities. African Journal of Biotechnology, 10, 5311-5319.

[25] Reddy, N.Y.A., Shaanker, R.U., Prasad, T.G. and Kumar, M.U. (2003) Physiological Approaches to Improve Harvest Index and Productivity in Sunflower. Helia, 26, 81-90. http://dx.doi.org/10.2298/HEL0338081R

[26] de Castro, C., Moreira, A., de Oliveira, R.F. and Dechen, A.R. (2006) Boro e estresse hídrico na produçao do girassol. Ciência e Agrotecnologia, 30. http://dx.doi.org/10.1590/S1413-70542006000200004 